\title{
Effect of Acetone-n-Butanol-Ethanol (ABE) as an Oxygenate on Combustion, Performance, and Emission Characteristics of a Spark Ignition Engine
}

\author{
Gang Wu, ${ }^{1}$ Deng Wu, ${ }^{1}$ Yuelin $\mathrm{Li}^{1}{ }^{1}$ and Lei Meng $\mathbb{D}^{2}$ \\ ${ }^{1}$ College of Automotive and Mechanical Engineering, Changsha University of Science and Technology, Changsha 410114, China \\ ${ }^{2}$ School of Automation, Wuhan University of Technology, Wuhan 430070, China \\ Correspondence should be addressed to Lei Meng; menglei1986@gmail.com
}

Received 25 September 2019; Accepted 11 December 2019; Published 6 January 2020

Guest Editor: Dezhi Zhou

Copyright (c) 2020 Gang Wu et al. This is an open access article distributed under the Creative Commons Attribution License, which permits unrestricted use, distribution, and reproduction in any medium, provided the original work is properly cited.

Ethanol is the most extensively used oxygenate for spark ignition (SI) engines. In comparison with ethanol, $n$-butanol exhibits a number of desirable properties for use in SI engines, which has proved to be a very promising oxygenated alternative fuel in recent years. However, the dehydration and recovery of bio- $n$-butanol consume extra money and energy in the acetone- $n$-butanolethanol (ABE) fermentation process. Hence, we focus on the research of ABE as a potential oxygenated alternative fuel in SI engines. The combustion, performance, and emission characteristics of B30, E30, ABE30 (i.e., 30 vol.\% $n$-butanol, ethanol, and ABE blended with 70 vol.\% gasoline), and G100 (pure gasoline) were compared in this study. The comparison results between B30, $\mathrm{E} 30$, and $\mathrm{ABE} 30$ at stoichiometric conditions show that ABE30 presents retarded combustion phasing, higher brake thermal efficiency, lower $\mathrm{CO}$ emissions, higher UHC emissions, and similar $\mathrm{NO}_{x}$ emissions. In comparison with G100 under various engine loads and equivalence ratios, for the most part, ABE30 exhibits $1.4 \%$ higher brake thermal efficiency, 14\% lower carbon monoxide, 9.7\% lower unburned hydrocarbons, and 23.4\% lower nitrogen oxides. It is indicated that ABE could be served as the oxygenate in spark ignition engine due to its capability to improve energy efficiency and reduce pollutant emissions.

\section{Introduction}

Depleting fuel resources and increasing environmental problems have driven the use of alternative fuel in engine [1-4]. Meanwhile, due to the demand of increasing gasoline octane, oxygenated alternative fuel including methyl tertiary butyl ether (MTBE), methanol, ethanol, and $n$-butanol have been investigated in spark ignition (SI) engines $[5,6]$. Poulopoulos and Philippopoulos [7] tested the effects of MTBE-gasoline blends on the performance and emissions of a four-cylinder OPEL 1.61 SI engine. Based on the emissions before and after three-way catalytic converter (TWC), it was found that the addition of MTBE decreased the emissions of hazardous exhaust gases, carbon monoxide (CO) and hydrocarbon ( $\mathrm{HC}$ ), only at high engine loading. Liu et al. [8] performed a study of SI engine fueled with methanol-gasoline fuel blends. Results showed that $\mathrm{CO}, \mathrm{HC}$, and nitrogen oxide $\left(\mathrm{NO}_{x}\right)$ emissions changed little before the TWC, and the conversion efficiencies of $\mathrm{HC}, \mathrm{CO}$, and $\mathrm{NO}_{x}$ emissions after the TWC are improved.

Ethanol is proposed as a replacement of MTBE and methanol in order to avoid gas station leakage and ground water pollution [9]. Hsieh et al. [10] conducted an experimental research on the performance and emission of an SI engine fueled with ethanol-gasoline blends based on the test of ethanol-gasoline blends with various blended ratios $(0$ vol. $\%, 5$ vol. $\%, 10$ vol. $\%, 20$ vol. $\%$, and 30 vol. $\%)$. When using ethanol, torque output and energy resource consumption increase and $\mathrm{CO}$ and $\mathrm{HC}$ emissions decrease dramatically, while the change of $\mathrm{NO}_{x}$ emission does not depend on the ethanol content. Celik [11] investigated the suitable blend ratio of ethanol in gasoline with high compression rate for SI engine. It was seen that engine power increased by $29 \%$, and the specific fuel consumption rate, and $\mathrm{CO}$, carbon dioxide $\left(\mathrm{CO}_{2}\right), \mathrm{NO}_{x}$, and $\mathrm{HC}$ combustion gas effluents were 
decreased by $3 \%, 53 \%, 10 \%, 19 \%$, and $12 \%$, respectively, when using 50 vol.\% blend ratio compared with pure gasoline.

Compared with ethanol, $n$-butanol has numbers of desirable properties as a fuel substitute of SI engines. Butanol is less prone to water contamination, and thus it could be distributed using the same infrastructure used to transport gasoline. Additionally, butanol also has lower latent heat, vapor pressure, higher heating value, octane, etc. [12]. The emission characteristics of an SI engine fueled with $n$-butanol-gasoline blends in combination with EGR were investigated by $\mathrm{Gu}$ et al. [13]. The addition of butanol to gasoline resulted in the decreasing engine's specific $\mathrm{CO}, \mathrm{HC}$, and $\mathrm{NO}_{x}$ combustion gas effluents. A study on the combustion characteristics of $n$-butanol in an SI engine was carried out by Szwaja and Naber [14]. The parameters of mass fraction burned (MFB), 0-10\% MFB combustion duration, $10-90 \%$ MFB combustion duration, and 50\% MFB location were calculated to quantitatively analyze the combustion properties. $n$-Butanol showed a shorter $0-10 \%$ MFB combustion duration, causing the shift of $50 \%$ MFB location towards top dead center (TDC). Meanwhile, $n$ butanol presented a higher combustion stability compared with gasoline from the viewpoint of coefficient of variation (COV).

$n$-Butanol belongs to the second-generation biofuels since it can be extracted from renewable sources, such as core fiber, wheat straw, distillers dry grains, corn stover, switchgrass, barely straw, and other plant materials [15-17]. $n$-Butanol is generally derived from acetone- $n$-butanolethanol (ABE) fermentation. However, due to low production efficiency, high hydration, and recovery cost during the fermentation process, $n$-butanol is currently less competitive in cost. Therefore, it is proposed that the intermediate fermentation outcome, i.e., $\mathrm{ABE}$, is used for alternative fuel.

The combustion and emissions performance of watercontaining ABE-diesel blends were studied by Chang et al. [18]. When using the blend of 20 vol.\% ABE, 0.5 vol. $\%$ water, and 79.5 vol.\% diesel (referred to as ABE20W0.5), brake thermal efficiency (BTE) was not only improved, but discharge of particular matter $(\mathrm{PM}), \mathrm{NO}_{x}$, polycyclic aromatic hydrocarbons (PAHs), and toxic equivalent of $\mathrm{PAH}\left(\mathrm{BaP}_{\mathrm{eq}}\right)$ were also reduced. Water-containing ABE-biodiesel-diesel blends were used to solve the problem of the increase of $\mathrm{NO}_{x}$ due to the use of biodiesel [19]. The addition of watercontaining $\mathrm{ABE}$ in biodiesel-diesel blend synchronously reduced $\mathrm{PM}$ and $\mathrm{NO}_{x}$ emissions by $4.30-30.7 \%$ and $10.9-$ $63.1 \%$, respectively. Lee's group did a lot of research experiments on ABE-diesel blends to test their spray and combustion properties [20-24]. The combustion duration of ABE-diesel blends is shorter, and the natural flame luminosity is lower in comparison with diesel, which indicated ABE-diesel blends had potential advantages of improving energy efficiency and reducing soot emission in engine. His group also tested the impacts of factors such as blend ratio, mixture formulation, and water addition on ABE-gasoline blends performance and emissions [25-27]. A phenomenological soot model considering the oxidation effect on soot density was proposed for ABE by Zhao et al. [28]. Luo et al. [29] used a wick-fed burner to evaluate soot tendency of ABE-diesel blends according to three parameters including flame height, threshold sooting index (TSI), and oxygenextended sooting index (OESI). Results showed that the high $\mathrm{H} / \mathrm{C}$ ratio and oxygen content of ethanol and $n$-butanol had a positive effect on reducing soot emission, while unsaturation degree of acetone had a negative effect. A multicomponent evaporation model was built to accurately predict the evaporation evolution of ABE-diesel blends, and the model was validated by the experimental results of droplet fiber suspension evaporation [30]. Van Geem et al. [31] proposed mechanisms of action involving 350 species and over 10,000 reactions, which explained the pyrolysis and oxidation processes of $\mathrm{ABE}$ in detail. The mechanism is proved to be feasible and valid based on the comparison between calculated and experimental laminar flame speed. Zhang et al. [32] based on the analysis of chemical kinetics, stretch effect, and laminar flame speed under various component ratios and equivalence ratios. It was seen the laminar flame speed followed the order of $\mathrm{ABE}(6: 3: 1)$ $<\operatorname{ABE}(3: 6: 1)<\operatorname{ABE}(1: 6: 3)$, and ethanol or $n$-butanol had a positive effect on burning velocity enhancement of $A B E$, while acetone had a negative effect.

As mentioned above, the previous research indicates $\mathrm{ABE}$ could be a potential substitute for engine fuel. However, there are few reports on the investigation of SI engine fueled by ABE-gasoline blends. Therefore, the experimental comparisons of the combustion, performance, and emission characteristics between E30, B30, ABE30 (i.e., 30 vol.\% ethanol, butanol and $\mathrm{ABE}$ blended with gasoline, respectively), and G100 (pure gasoline) were conducted in this study.

\section{Experimental Methods}

2.1. Fuel Preparation. The commercial gasoline with a research octane number (RON) of 92 was chosen as baseline fuel in the study. The ABE mixture was generated by stirring analytical grade acetone (99.5\%), $n$-butanol (99.5\%), and ethanol (99.8\%) using a temperature-controlled magnetic stirrer. The volume ratio of the mixture was set as $\mathrm{A}: \mathrm{B}: \mathrm{E}$ of $3: 6: 1$ which is the representative composition proportion of $\mathrm{ABE}$ fermentation products. The various parameters of each component in the mixture are listed in Table 1 [33-36]. The stability of the mixture was examined through a gravity test, where the mixture was stored in tubes for 14 days at $25^{\circ} \mathrm{C}$ and $1 \mathrm{~atm}$. The fuels showed a distinct single phase during the whole stability measurement process.

2.2. Engine Setup. Figure 1 shows the schematic diagram of the engine setup for the experiment. A port fuel-injected single cylinder SI engine is combined with a GE type TLC-15 class 4-35-1700 dynamometer, which can absorb loads up to $26 \mathrm{~kW}$ at speeds of $4500 \mathrm{rpm}$. The engine specifications are shown in Table 2. A Kistler-type 6125B pressure sensor was used to detect cylinder pressure, which was recorded by a LabVIEW code. The average in-cylinder pressures from 50 
TABLe 1: Properties of test fuels [33-36].

\begin{tabular}{|c|c|c|c|c|}
\hline Parameters & Gasoline & Acetone & Butanol & Ethanol \\
\hline Chemical formula & $\mathrm{C}_{4} \sim \mathrm{C}_{12}$ & $\mathrm{C}_{3} \mathrm{H}_{6} \mathrm{O}$ & $\mathrm{C}_{4} \mathrm{H}_{9} \mathrm{OH}$ & $\mathrm{C}_{2} \mathrm{H}_{5} \mathrm{OH}$ \\
\hline Lower heating value $(\mathrm{MJ} / \mathrm{kg})$ & 43.4 & 29.6 & 33.1 & 26.8 \\
\hline Density $\left(\mathrm{kg} / \mathrm{m}^{3}\right)$ & $715 \sim 765$ & 790 & 810 & 790 \\
\hline Energy density $\left(\mathrm{kJ} / \mathrm{m}^{3}\right)$ & 32.20 & 23.38 & 26.81 & 21.17 \\
\hline Octane number & 90 & - & 87 & 100 \\
\hline Oxygen content (wt.\%) & - & 27.6 & 21.6 & 34.8 \\
\hline Boiling temperature $\left({ }^{\circ} \mathrm{C}\right)$ & $25-215$ & 56.2 & 118 & 78 \\
\hline Latent heat of vaporation $\left(25^{\circ} \mathrm{C}\right)(\mathrm{kJ} / \mathrm{kg})$ & $380 \sim 500$ & 518 & 716 & 904 \\
\hline Self-ignition temperature $\left({ }^{\circ} \mathrm{C}\right)$ & $\sim 300$ & 465 & 343 & 420 \\
\hline Stoichiometric AFR & 14.7 & 9.0 & 11.2 & 9.0 \\
\hline Saturation pressure at $38^{\circ} \mathrm{C}(\mathrm{kPa})$ & $62 \sim 90$ & 53.4 & 2.27 & 13.8 \\
\hline Laminar flame speed $(\mathrm{cm} / \mathrm{s})$ & $\sim 33^{\mathrm{A}}$ & $\sim 34^{\mathrm{B}}$ & $\sim 48^{\mathrm{C}}$ & $\sim 48^{\mathrm{C}}$ \\
\hline
\end{tabular}

Note: ${ }^{\mathrm{A}} p=1 \mathrm{~atm}, T=325 \mathrm{~K} ;{ }^{\mathrm{B}} p=1 \mathrm{~atm}, T=298 \mathrm{~K} ;{ }^{\mathrm{C}} p=1 \mathrm{~atm}, T=343 \mathrm{~K}$.

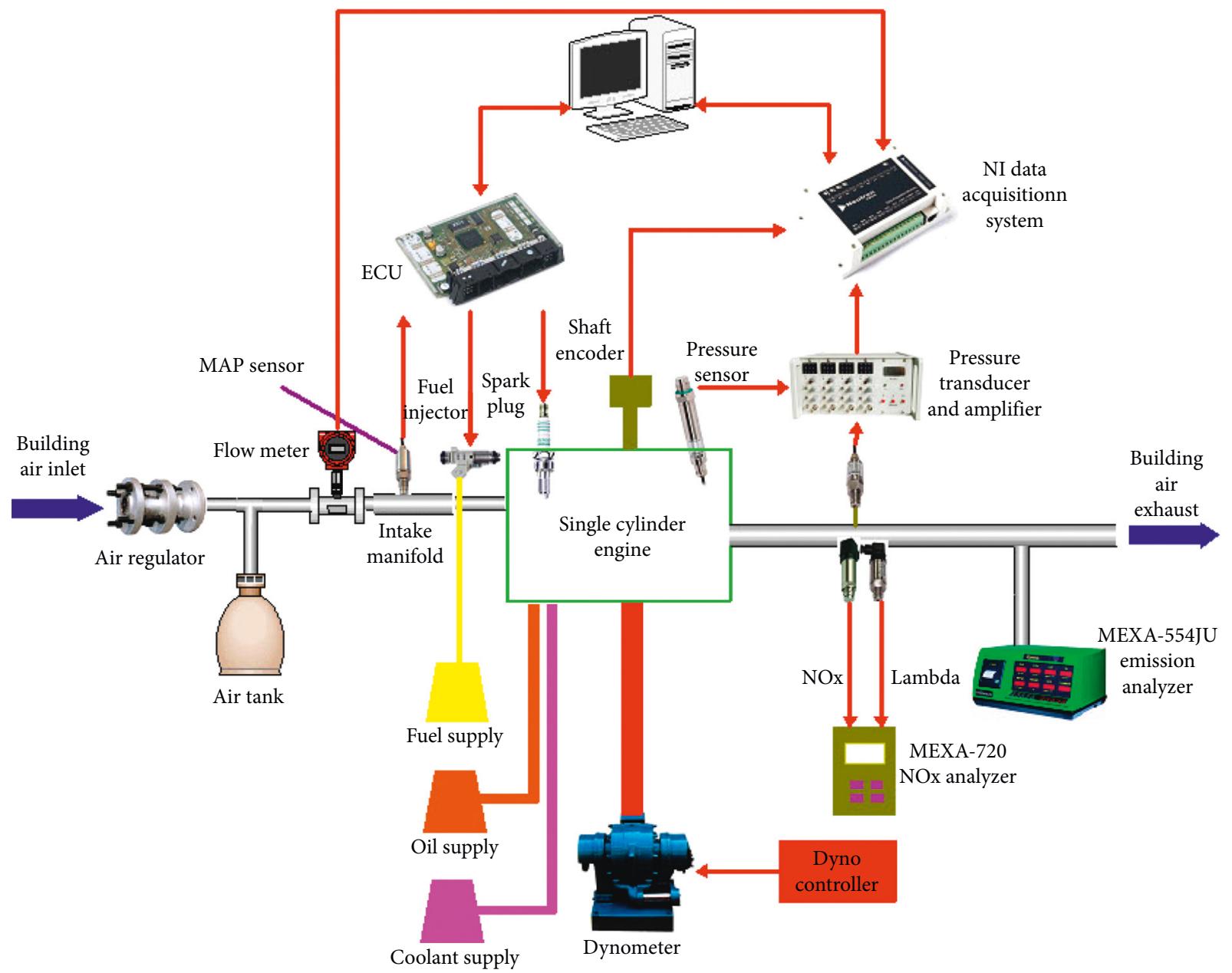

FIGURE 1: Engine setup.

cycles were calculated at each test point. BEI XH25D shaft encoder was used to measure the crank angle location. The Megasquirt V3.0 Engine Control Unit (ECU) was used for engine control. The dynamometer is dominated by a DYNLOC controller. The engine throttle location was adjusted by DyneSystems DTC-1 digital throttle controller. Air/fuel ratio (AFR) and $\mathrm{NO}_{x}$ emission were detected by Horiba MEXA-720 analyzer. UHC and CO emissions were detected by Horiba MEXA-554JU analyzer. The intake air system provided compressed, filtered air from the building to the engine. The flow of air from the building supply system was controlled by an electronic regulator which provided pressure control; from which the air flowed through a surge tank and then into the intake manifold. An intake air temperature sensor and a manifold absolute pressure (MAP) sensor were mounted at the intake manifold directly to 
TABLE 2: Engine specifications.

\begin{tabular}{lc}
\hline Engine type & SI engine \\
\hline Displaced volume $\left(\mathrm{cm}^{3}\right)$ & 575 \\
Stroke $(\mathrm{mm})$ & 90.1 \\
Bore $(\mathrm{mm})$ & 90.3 \\
Connecting rod length $(\mathrm{mm})$ & 150.7 \\
Compression ratio & $9.6: 1$ \\
Number of valves & 4 \\
Number of cylinders & 1 \\
\hline
\end{tabular}

measure intake air temperature and pressure. The air then flowed through a throttle body where the throttle valve was controlled with a throttle position sensor. From there, the air was mixed with the injected fuel and flowed into the engine via the intake valves. A Bosch fuel injector rated at $440 \mathrm{~cm}^{3}$ / min was used at a fuel pressure of 3 bar. The measuring range, accuracy and resolution of experimental apparatus are shown in Table 3.

2.3. Test Conditions. The engine rotational velocity was set at a fixed value of $1200 \mathrm{rpm}$ in this research. The throttle plate was adjusted to be fully open and the intake manifold pressure was fixed at $60 \mathrm{kPa}$ and $90 \mathrm{kPa}$ by regulating the compressed air supply, which corresponded to engine loads of 3 bar BMEP (brake mean effective pressure) and 5 bar BMEP. The intake air pressure was controlled using an electronic regulator which provides precise control. Meanwhile, the equivalence ratio was varied over a range of lean, stoichiometric and rich conditions, i.e., lambda varying from 1.2 to 0.8 . In a practical SI engine operating condition, equivalence ratio is not uniform and varies in each individual cylinder on a cycle-by-cycle basis. For example, it is advantageous to use lean condition for best efficiency at part-load operation and rich condition for maximum power at full-load operation. Therefore, the equivalence ratio in this study was varied over a range of lean, stoichiometric, and rich conditions, i.e., $\Phi$ ranging from 0.83 to 1.25 . In this study, the maximum brake torque (MBT) timing of gasoline was chosen as spark timing. The measured UHC, CO, and pollution gas temperature were directly recorded from the emissions analyzer, while the measured values of engine torque, lambda, and $\mathrm{NO}_{x}$ were averaged within 60 -second period. The experiments were conducted three times, and each group of data was collected for one day. The average of these datasets was then calculated. The tests were performed on three consecutive days in a temperature-controlled laboratory, so the effects of humidity were assumed to be negligible. Furthermore, the engine was allowed to run at every operating condition for an extended period of time to ensure steady state measurements. The test conditions mentioned above are summarized in Table 4.

\section{Results and Discussion}

3.1. Comparison between E30, B30, and ABE30 under Stoichiometric Condition. Figure 2 compares the combustion characteristics of E30, B30, and $\mathrm{ABE} 30$ at $\Phi=1$ and 3 bar BMEP. It can be seen from Figure 2(a) that E30 showed a
TABLE 3: Measuring range, accuracy, and resolution of the experimental apparatus.

\begin{tabular}{lccc}
\hline Apparatus & Measuring range & $\begin{array}{c}\text { Accuracy } \\
( \pm)\end{array}$ & Resolution \\
\hline Engine speed & $1-5000 \mathrm{rpm}$ & $0.2 \%$ & $1 \mathrm{rpm}$ \\
Torque & $0-300 \mathrm{Nm}$ & $0.5 \%$ & $0.1 \mathrm{Nm}$ \\
Exhaust gas & $0-900^{\circ} \mathrm{C}$ & $1{ }^{\circ} \mathrm{C}$ & $0.1^{\circ} \mathrm{C}$ \\
temperature & $0-10 \% \mathrm{vol}$ & $0.06 \%$ & $0.01 \% \mathrm{vol}$ \\
$\mathrm{CO}$ emission & $0-10000 \mathrm{ppm} \cdot \mathrm{vol}$ & $12 \mathrm{ppm} \cdot \mathrm{vol}$ & $1 \mathrm{ppm} \cdot \mathrm{vol}$ \\
$\mathrm{HC}$ emission & $0-20 \% \mathrm{vol}$ & $0.5 \%$ & $0.01 \% \mathrm{vol}$ \\
$\mathrm{CO}_{2}$ emission & $0-3000 \mathrm{ppm}$ & $3 \%$ & $1 \mathrm{ppm}$ \\
$\mathrm{NO}_{x}$ emission & $0.65-13.7$ & $0.3 \%$ & 0.01 \\
$\mathrm{Lambda}^{\text {Mass flow meter }}$ & $0-1000 \mathrm{slpm}$ & $1 \%$ & $0.1 \mathrm{slpm}$ \\
\hline
\end{tabular}

TABle 4: Test conditions.

\begin{tabular}{lc}
\hline Throttle position (\%) & 100 \\
Engine speed (rpm) & 1200 \\
Load (bar BMEP) & 3 and 5 \\
Lamda & $0.8 \sim 1.2$ \\
Fuel pressure (bar) & 3 \\
Spark timing & Gasoline's MBT at $\Phi=1$ \\
\hline
\end{tabular}

more advanced combustion phasing, resulting in the highest peak cylinder pressure. To further evaluate the combustion phasing of different fuels, normalized mass fraction burnt (MFB) shown in Figure 2(b) was calculated from pressure trace using Rassweiler and Withrow method [37, 38]. Based on MFB profiles, initial combustion duration (ICD) given by $0-10 \%$ MFB, major combustion duration (MCD) given by $10-90 \% \mathrm{MFB}$, and 50\% MFB location were obtained as shown in Figure 2(c). During the ICD, the combustion rate was mainly impacted by laminar flame speed (LFS) $[14,39]$. Based on the highest LFS, E30 obtained the 2.0\% and 4.1\% shorter ICD compared with B30 and ABE30. In addition, it should be noted that ethanol had the same LFS with butanol (see Table 1), but got the shorter ICD probably due to fuel volatility. It was known that the latent heat of vaporization and vapor pressure were two important thermodynamic properties that affect fuel volatility [40]. Vapor pressure was an important property affecting the volatility of a fuel. The vapor pressure of butanol was much lower than that of ethanol, which meant that butanol needed a higher temperature or longer time to get completely vaporized [41]. Moreover, the higher oxygen content of ethanol was beneficial to improve combustion rate due to chemical affect. The MCD of the fuels followed a similar sequence with the ICD. The higher pressure built during the period of ICD promoted the mixing of fuel and air due to the increase in turbulence and improved the combustion rate in the following flame propagation. Based on the shorter ICD and $\mathrm{MCD}$, E30 got the 0.5 CA and 0.81 CA advanced 50\% MFB location when compared to B30 and ABE30.

Figure 3 compares the engine performance of E30, B30, and ABE30, including BTE and BSFC at $\Phi=1$ and 3 bar BMEP. The BTE indicates how well an engine can convert the heat in fuel to mechanical energy. From Figure 3(a), the 


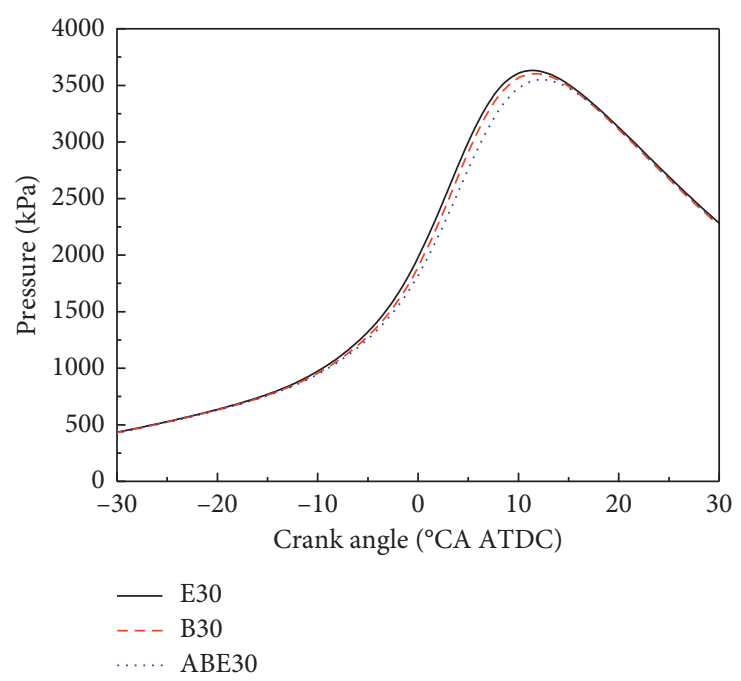

(a)

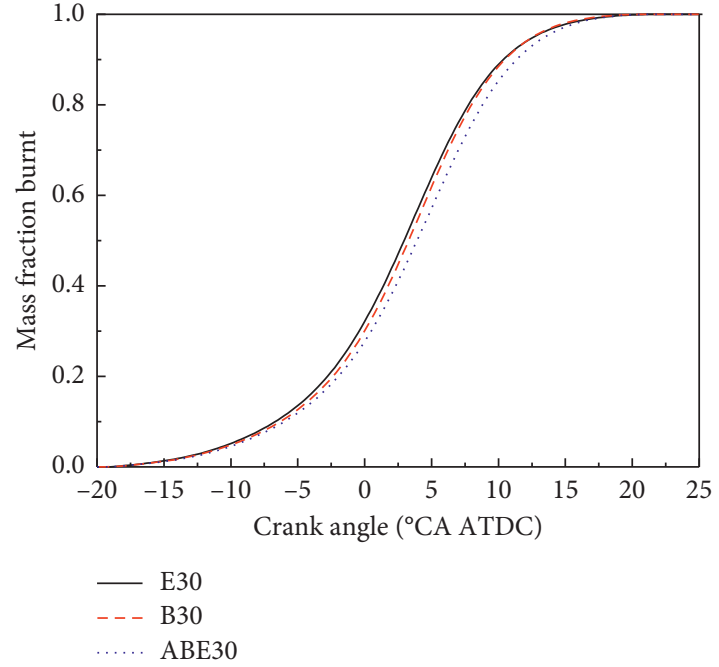

(b)

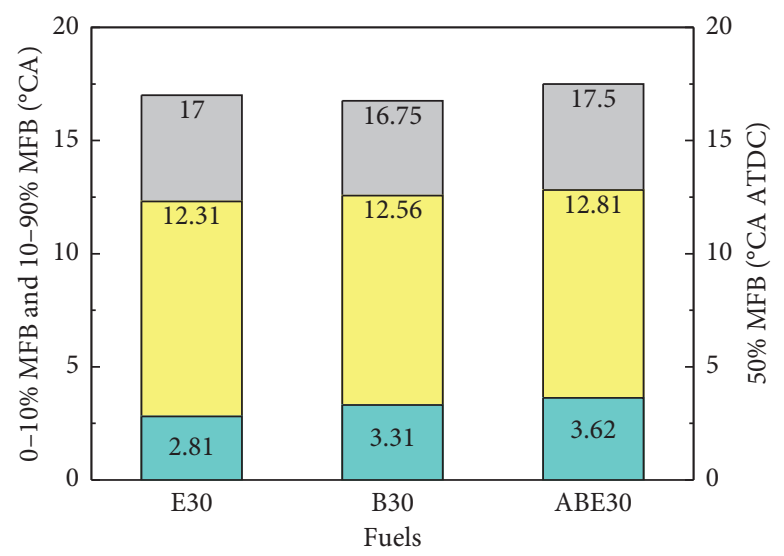

$0-10 \%$ MFB

$10-90 \%$ MFB

$50 \%$ MFB

(c)

FIGURE 2: Combustion characteristics of E30, B30, and ABE30 at 3 bar BMEP under stoichiometric condition.

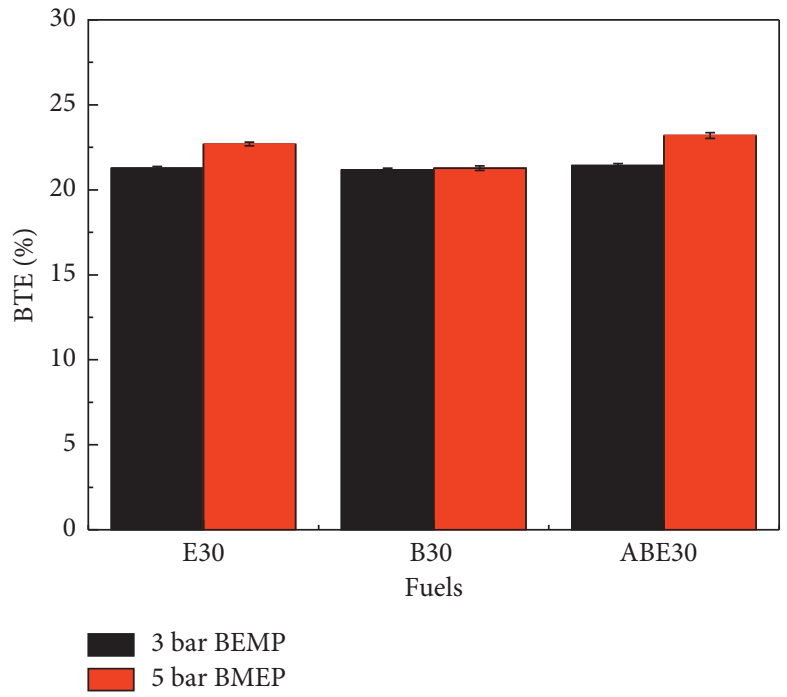

(a)

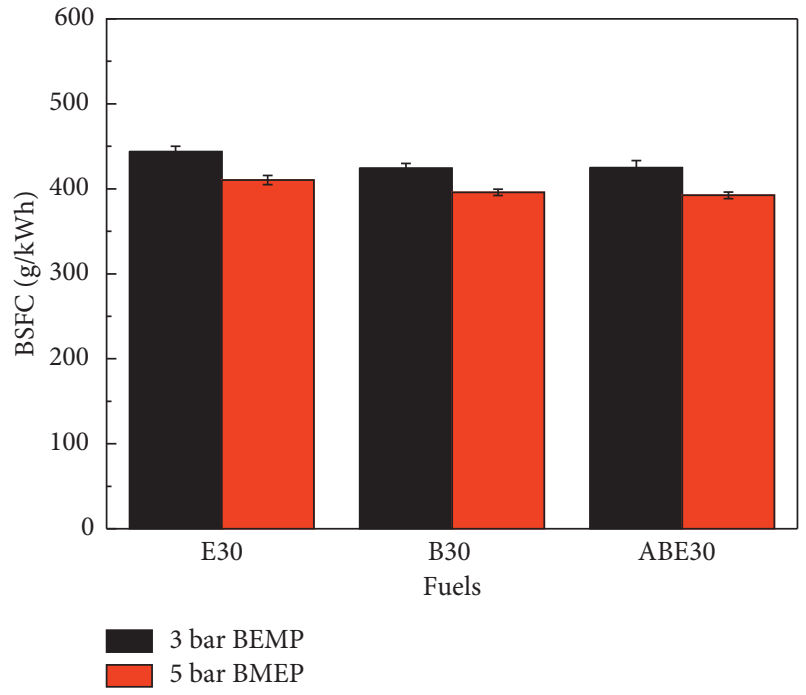

(b)

Figure 3: Engine performance of E30, B30, and ABE30 at 3 and 5 bar BMEP under stoichiometric condition. 


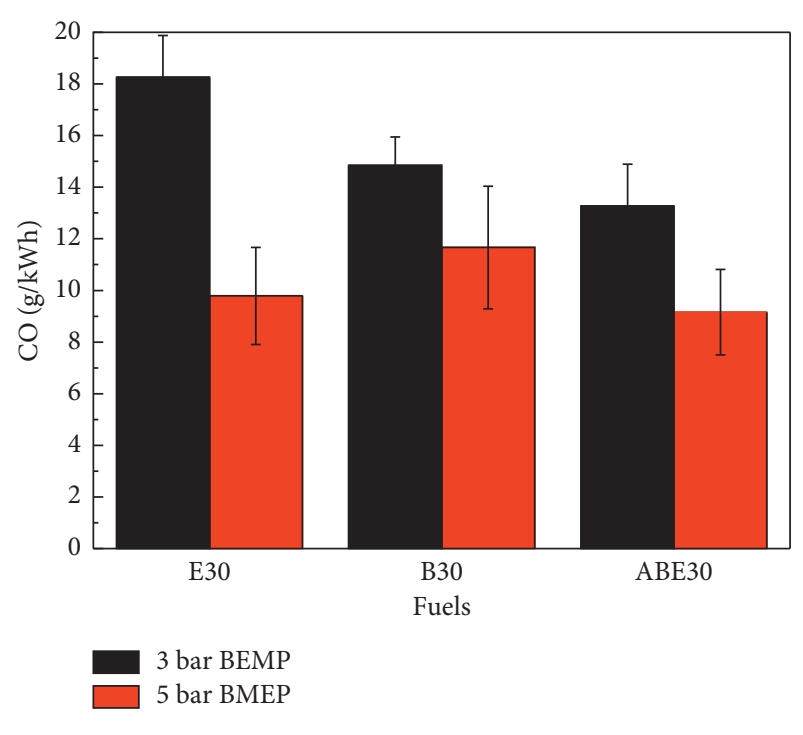

(a)

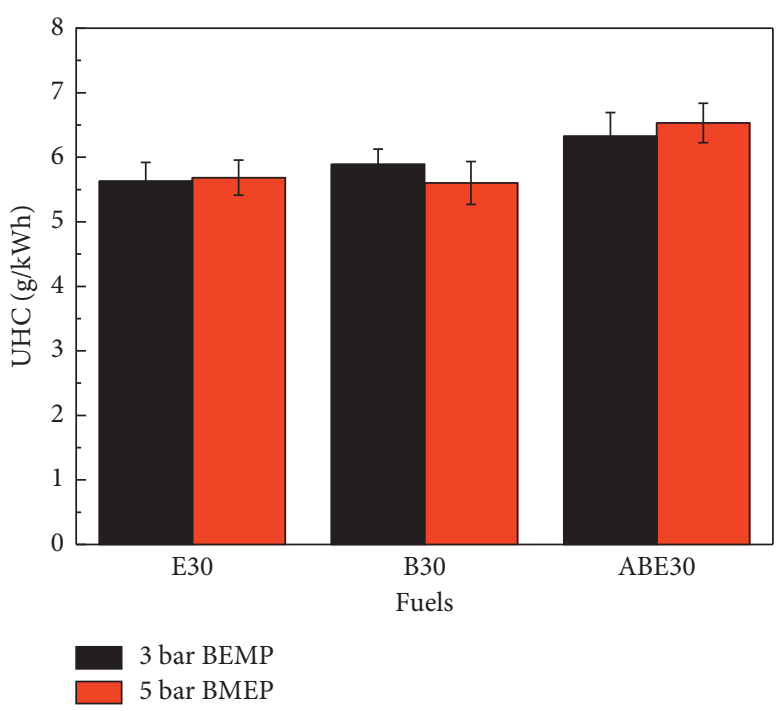

(b)

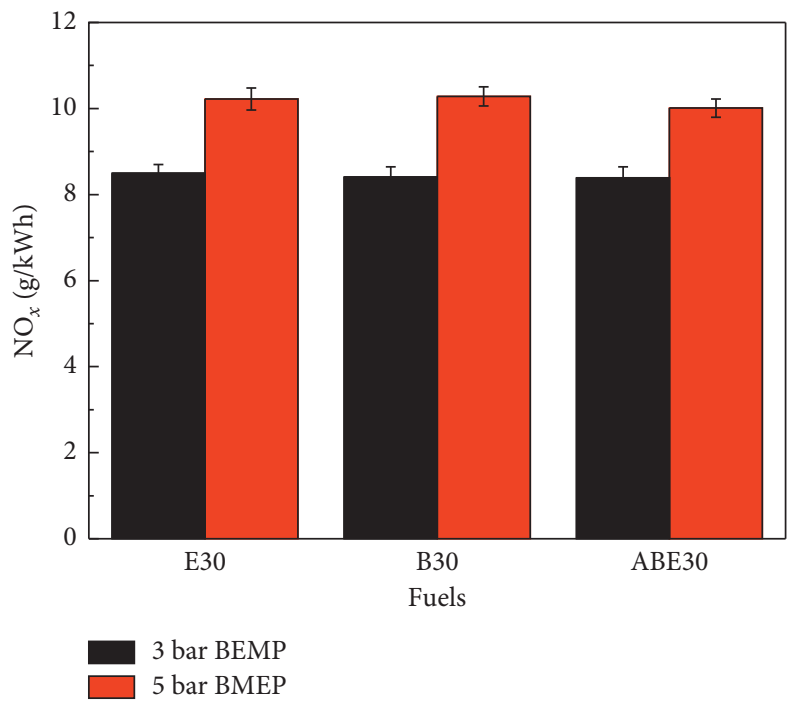

(c)

FIgure 4: Engine emissions of E30, B30, and ABE30 at 3 and 5 bar BMEP under stoichiometric condition.

results showed that $\mathrm{ABE} 30$ had $0.7 \%$ and $1.1 \%$ higher $\mathrm{BTE}$ than that of E30 and B30, respectively. This can be explained that the advanced combustion phasing after adding ethanol and butanol led to the subsequent increase of work lost in compression process and decrease of net useful work when spark timing was set to gasoline's MBT $[42,43]$. For the BSFC, ethanol showed the maximum value due to its lower energy density. In addition, it can be seen that the engine had a relatively high fuel consumption, which is due to the high friction owing to it being a single-cylinder engine; it could also be caused by carbon deposition in the engine, or aging of the sparkplug.

Figure 4 shows the $\mathrm{CO}, \mathrm{UHC}$, and $\mathrm{NO}_{x}$ emissions of E30, B30, and ABE30 at $\Phi=1$ and 3 bar BMEP. A higher CO emission occurred for E30. Generally, a higher CO emission level can be caused by the conditions of locally rich, insufficient oxidizer, or low combustion temperature. After adding fuel oxygenates, the lack of oxygen should not lead to the increased $\mathrm{CO}$ emission. Previous studies explained that the fuel producing more products in terms of heat capacity of the combustion products can lower combustion temperature and further slow down the oxidation process of $\mathrm{CO}$ emission $[44,45]$. The stoichiometric chemical reactions of acetone, ethanol, and $n$-butanol are listed equation (1). Moreover, E30 had a shorter combustion duration, and thus insufficient oxidation of $\mathrm{CO}$ could also cause the increased $\mathrm{CO}$ emission. UHC emission was mainly influenced by the combustion quality. The higher oxygen content in E30 was beneficial to improve combustion quality, resulting in a lower UHC emission compared to B30 and ABE30. Zeldovich thermal activation was the predominate mechanism for $\mathrm{NO}_{x}$ emission formation from internal combustion engines. The higher combustion temperature and local oxygen concentration in the peak temperature zone were in 


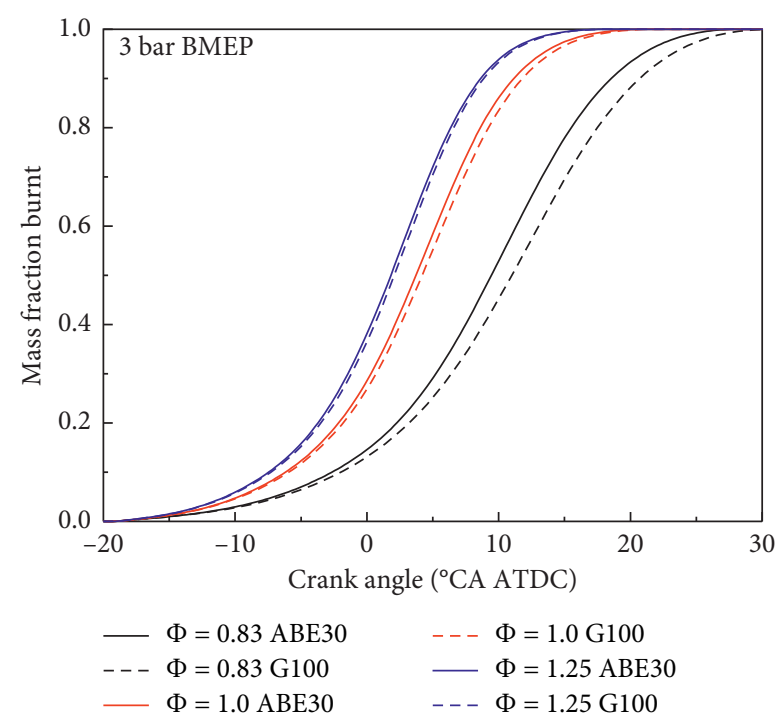

(a)
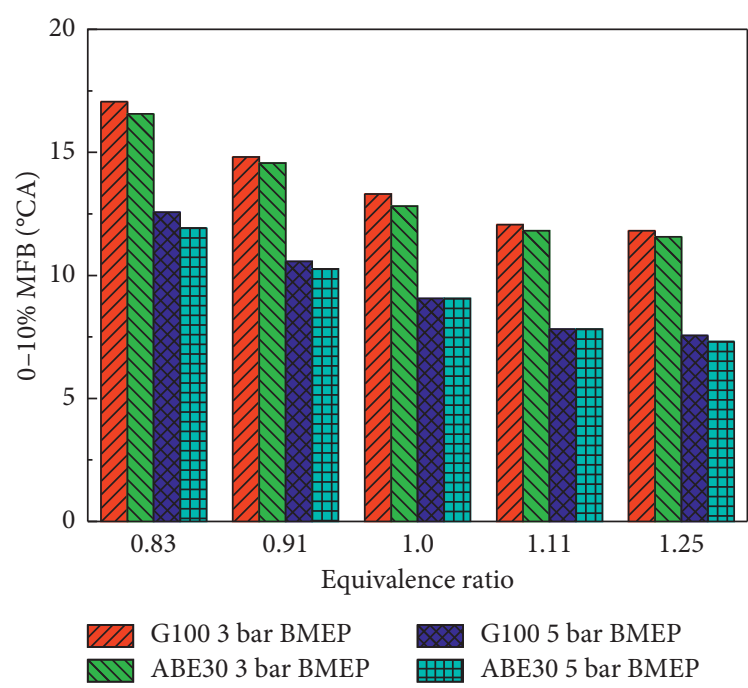

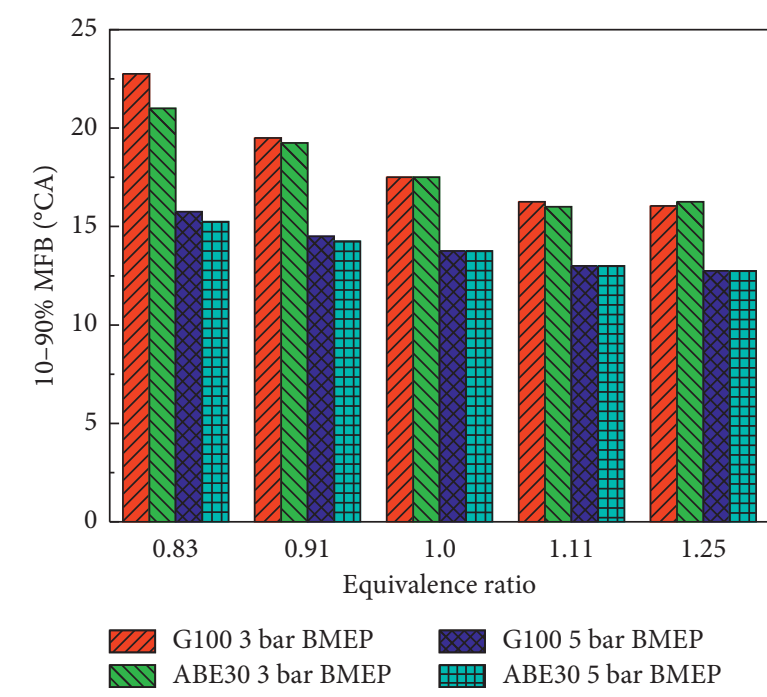

(b)

(c)

FIgURE 5: Combustion characteristics of ABE30 and G100 under various engine loads and equivalence ratios.

favor of $\mathrm{NO}_{x}$ emission formation [46]. By using fuel oxygenates, an increased oxygen concentration was caused due to fuel self-provided oxygen, but a lower combustion temperature could also be resulted. Based on the competition between the factors, the similar $\mathrm{NO}_{x}$ was finally obtained by E30, B30, and ABE30.

$$
\begin{aligned}
& \text { Acetone: } 2.58 \mathrm{C}_{3} \mathrm{H}_{6} \mathrm{O}+10.33\left(\mathrm{O}_{2}+3.785 \mathrm{~N}_{2}\right)=7.74 \mathrm{CO}_{2}+7.74 \mathrm{H}_{2} \mathrm{O}+39.10 \mathrm{~N}_{2} \\
& \text { butanol: } 1.72 \mathrm{C}_{4} \mathrm{H}_{9} \mathrm{OH}+10.33\left(\mathrm{O}_{2}+3.785 \mathrm{~N}_{2}\right)=6.88 \mathrm{CO}_{2}+8.60 \mathrm{H}_{2} \mathrm{O}+39.10 \mathrm{~N}_{2} \\
& \text { ethanol: } 3.44 \mathrm{C}_{2} \mathrm{H}_{5} \mathrm{OH}+10.33\left(\mathrm{O}_{2}+3.785 \mathrm{~N}_{2}\right)=6.88 \mathrm{CO}_{2}+10.32 \mathrm{H}_{2} \mathrm{O}+39.10 \mathrm{~N}_{2}
\end{aligned}
$$

\subsection{Comparison between $G 100$ and ABE30 under Various} Engine Loads and Equivalence Ratios. In this section, the performance, combustion, and emission characteristics of ABE30 and G100 were compared under different equivalence ratios $(\Phi=0.83 \sim 1.25)$ and engine loads ( 3 and 5 bar BMEP). It was apparent that the ICD and MCD were reduced with increasing equivalence ratios and engine loads. A higher cylinder temperature was achieved at 5 bar BMEP, which led to a faster combustion rate. Gauthier et al. [47] discovered that when the equivalence ratio increased, the ICD decreased. A similar trend was also obtained in Figure 5(b). A similar trend was also obtained in Figure 5(b). 


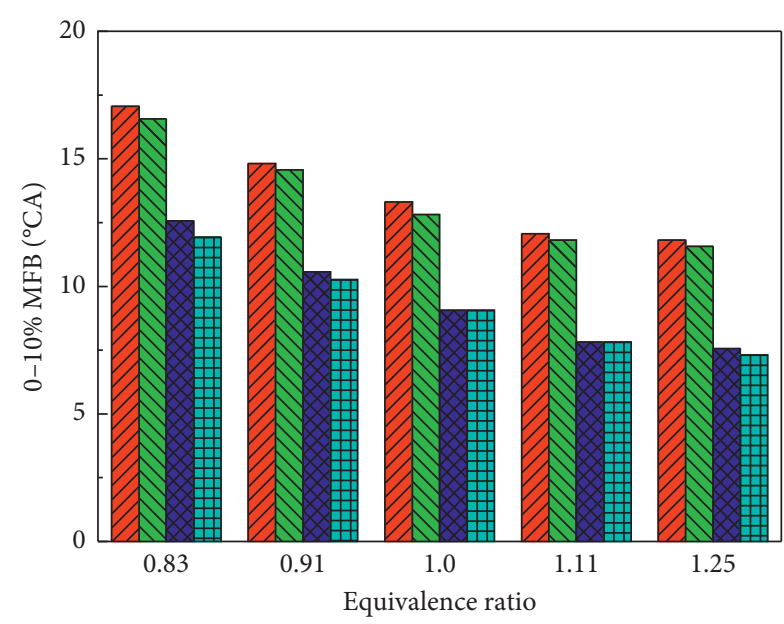

VIA G100 3 bar BMEP G100 5 bar BMEP MIV ABE30 3 bar BMEP 回 ABE30 5 bar BMEP

(a)
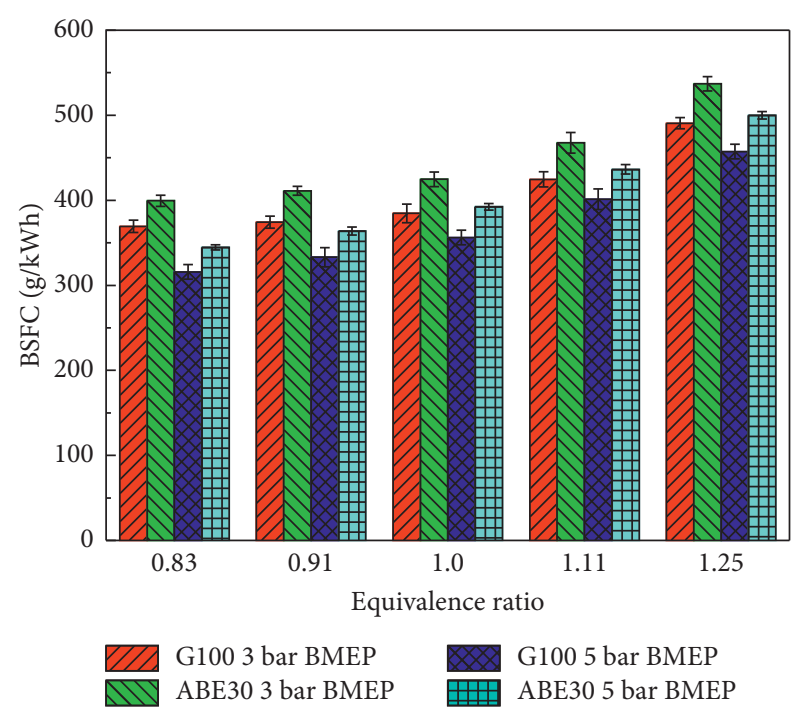

(b)

FIGURE 6: Engine performance of ABE30 and G100 under various engine loads and equivalence ratios.

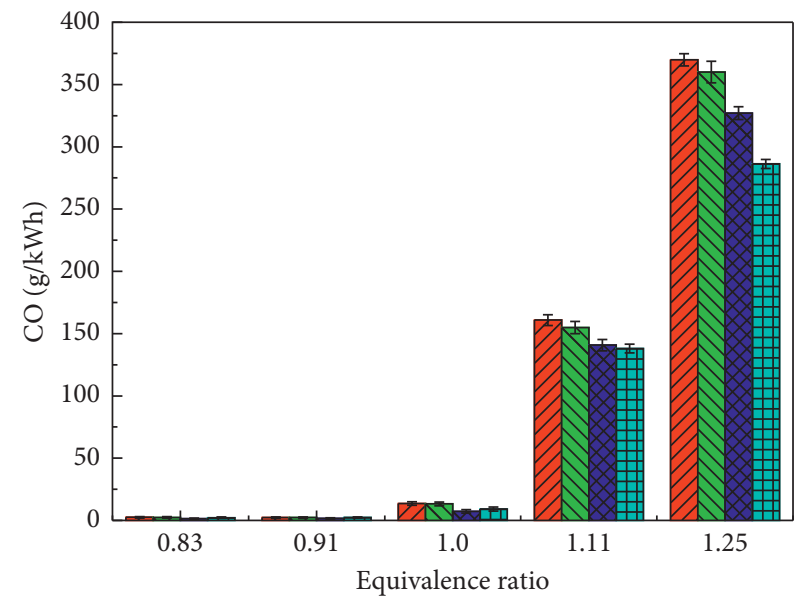

G100 3 bar BMEP ABE30 3 bar BMEP

$$
\text { ABE30 } 5 \text { bar BMEP }
$$

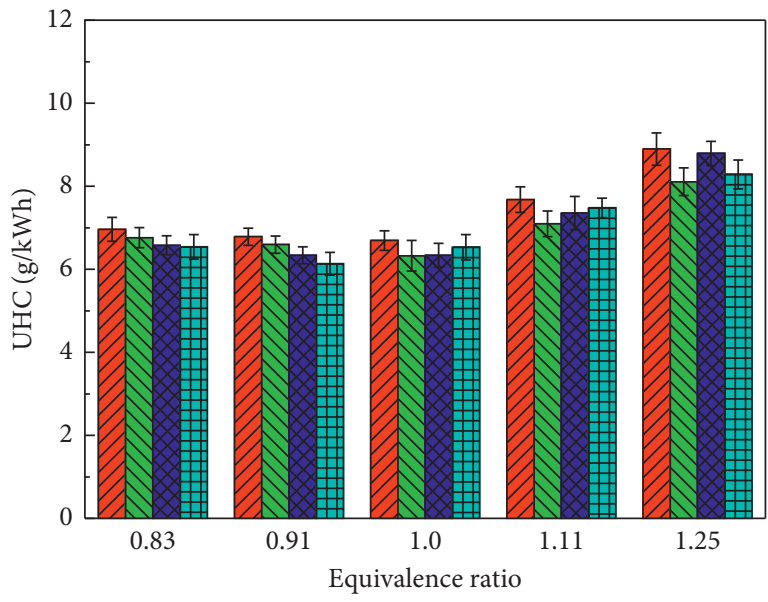

G100 3 bar BMEP G100 5 bar BMEP ABE30 3 bar BMEP \#四 ABE30 5 bar BMEP

(b)

(a)

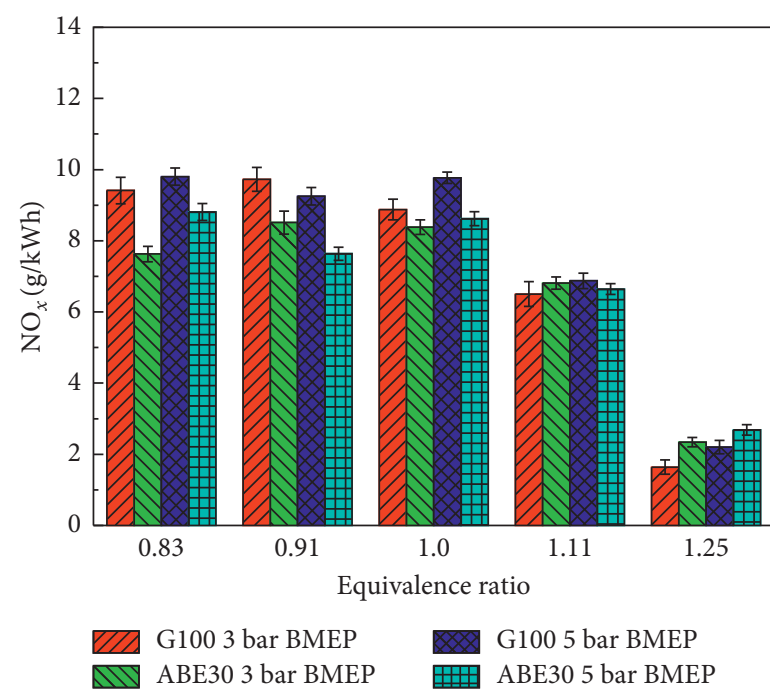

(c) 
In addition, with the increases of equivalence ratios and engine loads, the differences of ICD and MCD between ABE30 and G100 were reduced. These trends were consistent with those of $[47,48]$. In general, compared with G100, ABE30 had a more advanced combustion phasing with $1.7-3.9 \%$ shorter ICD and $1.2-8.3 \%$ shorter MCD.

Figure 6 shows the BTE and BSFC of ABE30 and G100 with respect to equivalence ratio and engine load. The BTE increased with decreasing equivalence ratio and increasing engine load. That was based on the fact that combustion was not complete in the rich conditions. With the further decrease of equivalence ratio, increased dilution improved isentropic efficiency by decreasing heat loss and increasing adiabatic exponent due to the lower temperatures than that in stoichiometric conditions [49]. The higher cylinder temperature at 5 bar BMEP resulted in the improved combustion quality and higher BTE than that at 3 bar BMEP. For the BTE, ABE30 increased BTE by $0.2-1.4 \%$ compared with G100 due to the improved combustion quality and shorter combustion duration, and apparent increase occurred at lean conditions. This could be explained that the combustion phasing of fuels was retarded at lean conditions, but the engine was still running at gasoline's MBT at stoichiometric condition, and thus the advanced combustion phasing of ABE30 was more suitable as shown in Figure 5(a), and the side effect of improper combustion phasing of $\mathrm{ABE}$ at stoichiometric and rich conditions was avoided. Due to the improved BTE, the BSFC of fuels was decreased with decreasing equivalence ratio and increasing engine load. Based on the lower energy density, ABE30 showed 8.1-10.4\% higher BSFC than that of G100.

Figure 7 shows the variations of $\mathrm{CO}, \mathrm{UHC}$, and $\mathrm{NO}_{x}$ emissions with equivalence ratio and engine load for ABE30 and G100. It was observed that the equivalence ratio controlled CO emission until lean conditions were reached, and after that $\mathrm{CO}$ emission did not vary significantly. This low $\mathrm{CO}$ emission under lean condition can be explained by the fact that there was more than enough oxygen available to carry on the oxidation process [48]. In addition, the lower $\mathrm{CO}$ emission and higher $\mathrm{NO}_{x}$ were attained in the higher engine load due to the higher cylinder temperature. When compared with G100, ABE30 produced the $1.3-14 \%$ lower $\mathrm{CO}$ and $0.5-9.7 \%$ lower UHC emissions due to the improved combustion quality as a result of fuel-borne oxygen. UHC emission increased for rich conditions because of incomplete combustion as the combustion quality deteriorates. In comparison with G100, although an increased oxygen concentration was provided, a deceased combustion temperature was also caused as mentioned above so that the final 3.4-23.4\% lower $\mathrm{NO}_{x}$ emission was produced at lean and stoichiometric conditions for ABE30. It was also observed that $\mathrm{ABE} 30$ presented a higher $\mathrm{NO}_{x}$ emission compared with G100 at $\Phi=1.25$. It probably resulted from the fuel-rich prompt mechanism of $\mathrm{NO}_{x}$ emission formation, which meant more hydrocarbon radicals generated from ABE30 due to the lower molecular weight and more injected amounts of fuel increased the formation of $\mathrm{HCN}$ and led to the higher $\mathrm{NO}_{x}$ emission [46].

\section{Conclusions}

This study investigates the potential of ABE-gasoline blend as a green fuel for SI engines. The comparisons of combustion, performance, and emission characteristics between E30, B30, ABE30, and G100 are analyzed.

The comparisons between E30, B30, and $\mathrm{ABE} 30$ at stoichiometric condition show that $\mathrm{E} 30$ and $\mathrm{B} 30$ had a more advanced combustion, causing the lower BTE than that of ABE30. The significant increase of CO and UHC emissions occurred for E30 and ABE30, respectively. A similar $\mathrm{NO}_{x}$ was obtained by E30, B30, and ABE30.

ABE30 was further compared with G100 under various equivalence ratios and engine loads. ABE30 had a generally advanced combustion phasing, and the difference of combustion phasing between ABE30 and G100 was decreased with increasing equivalence ratio and engine load. For engine performance and emissions, compared with G100, the higher BTE (0.2-1.4\%) and the lower CO (1.3-14\%), UHC (0.5-9.7\%) and $\mathrm{NO}_{x}(3.4-23.4 \%)$ emissions were observed for IBE30 in some conditions.

\section{Nomenclature}

ABE: Acetone- $n$-butanol-ethanol

SI: $\quad$ Spark ignition

ATDC: After top dead center

BMEP: Brake mean effective pressure

$\Phi: \quad$ Equivalence ratio

RON: Research octane number

BSFC: Brake-specific fuel consumption

PM: Particular matter

MTBE: Methyl tertiary butyl ether

ICD: Initial combustion duration

BTE: Brake thermal efficiency

ECU: Engine control unit

MFB: Mass fraction burned

UHC: Unburned hydrocarbons

CO: $\quad$ Carbon monoxide

$\mathrm{NO}_{x}: \quad$ Nitrogen oxides

COV: Coefficient of variation

PAHs: Polycyclic aromatic hydrocarbons

$\mathrm{CO}_{2}$ : Carbon dioxide

MCD: Major combustion duration.

\section{Data Availability}

All data used to support the findings of this study are included within the article.

\section{Conflicts of Interest}

The authors declare that they have no conflicts of interest regarding the publication of this paper.

\section{Acknowledgments}

This work was supported by the National Natural Science Foundation of China (grant nos. 51976016 and 61903287). The authors also thank the Open Research Subject of State 
Key Laboratory of Engines, China, (grant no. K2018-07), and the Research Foundation of Education Bureau of Hunan Province (grant no. 18B149) for their support.

\section{References}

[1] M. F. Othman, A. Adam, G. Najafi, and R. Mamat, "Green fuel as alternative fuel for diesel engine: a review," Renewable and Sustainable Energy Reviews, vol. 80, pp. 694-709, 2017.

[2] E. Jiaqiang, M. Zhao, Q. Zuo et al., "Effects analysis on diesel soot continuous regeneration performance of a rotary microwave-assisted regeneration diesel particulate filter," Fuel, vol. 260, Article ID 116353, 2019, In press.

[3] E. Jiaqiang, M. Zhao, G. Liu et al., "Effects analysis on optimal microwave energy consumption in the heating process of composite regeneration for the diesel particulate filter," Applied Energy, vol. 254, Article ID 113736, 2019.

[4] E. Jiaqiang, G. Liu, Z. Zhang et al., "Effect analysis on cold starting performance enhancement of a diesel engine fueled with biodiesel fuel based on an improved thermodynamic model," Applied Energy, vol. 243, pp. 321-335, 2019.

[5] Y. Li, W. Tang, Y. Chen, J. Liu, and C.-f. F. Lee, "Potential of acetone-butanol-ethanol (ABE) as a biofuel," Fuel, vol. 242, pp. 673-686, 2019.

[6] X. Zhao, E. Jiaqiang, Z. Zhang et al., "A review on heat enhancement in thermal energy conversion and management using field synergy principle," Applied Energy, vol. 257, Article ID 113995, 2019, In press.

[7] S. Poulopoulos and C. Philippopoulos, "Influence of MTBE addition into gasoline on automotive exhaust emissions," Atmospheric Environment, vol. 34, no. 28, pp. 4781-4786, 2000.

[8] S. Liu, E. R. Cuty Clemente, T. Hu, and Y. Wei, "Study of spark ignition engine fueled with methanol/gasoline fuel blends," Applied Thermal Engineering, vol. 27, no. 11-12, pp. 1904-1910, 2007.

[9] R. K. Niven, "Ethanol in gasoline: environmental impacts and sustainability review article," Renewable and Sustainable Energy Reviews, vol. 9, no. 6, pp. 535-555, 2005.

[10] W.-D. Hsieh, R.-H. Chen, T.-L. Wu, and T.-H. Lin, "Engine performance and pollutant emission of an SI engine using ethanol-gasoline blended fuels," Atmospheric Environment, vol. 36, no. 3, pp. 403-410, 2002.

[11] M. B. Celik, "Experimental determination of suitable ethanolgasoline blend rate at high compression ratio for gasoline engine," Applied Thermal Engineering, vol. 28, no. 5-6, pp. 396-404, 2008.

[12] P. Dürre, "Biobutanol: an attractive biofuel," Biotechnology Journal, vol. 2, no. 12, pp. 1525-1534, 2007.

[13] X. Gu, Z. Huang, J. Cai, J. Gong, X. Wu, and C.-f. Lee, "Emission characteristics of a spark-ignition engine fuelled with gasoline- $n$-butanol blends in combination with EGR," Fuel, vol. 93, pp. 611-617, 2012.

[14] S. Szwaja and J. D. Naber, "Combustion of $n$-butanol in a spark-ignition IC engine,” Fuel, vol. 89, no. 7, pp. 1573-1582, 2010.

[15] M. Kumar and K. Gayen, "Developments in biobutanol production: new insights," Applied Energy, vol. 88, no. 6, pp. 1999-2012, 2011.

[16] C.-L. Cheng, P.-Y. Che, B.-Y. Chen, W.-J. Lee, C.-Y. Lin, and J.-S. Chang, "Biobutanol production from agricultural waste by an acclimated mixed bacterial microflora," Applied Energy, vol. 100, pp. 3-9, 2012.
[17] A. Ranjan, S. Khanna, and V. S. Moholkar, "Feasibility of rice straw as alternate substrate for biobutanol production," Applied Energy, vol. 103, pp. 32-38, 2013.

[18] Y.-C. Chang, W.-J. Lee, S.-L. Lin, and L.-C. Wang, "Green energy: water-containing acetone-butanol-ethanol diesel blends fueled in diesel engines," Applied Energy, vol. 109, pp. 182-191, 2013.

[19] Y.-C. Chang, W.-J. Lee, T. S. Wu, C.-Y. Wu, and S.-J. Chen, "Use of water containing acetone-butanol-ethanol for $\mathrm{NO}_{x}-\mathrm{PM}$ (nitrogen oxide-particulate matter) trade-off in the diesel engine fueled with biodiesel," Energy, vol. 64, pp. 678-687, 2014.

[20] N. Zhou, M. Huo, H. Wu, K. Nithyanandan, C.-f. F. Lee, and Q. Wang, "Low temperature spray combustion of acetonebutanol-ethanol (ABE) and diesel blends," Applied Energy, vol. 117, pp. 104-115, 2014.

[21] H. Wu, K. Nithyanandan, N. Zhou, T. H. Lee, C.-f. F. Lee, and C. Zhang, "Impacts of acetone on the spray combustion of acetone-butanol-ethanol (ABE)-diesel blends under low ambient temperature," Fuel, vol. 142, pp. 109-116, 2015.

[22] H. Wu, K. Nithyanandan, T. H. Lee, C.-f. F. Lee, and C. Zhang, "Spray and combustion characteristics of neat acetone-butanol-ethanol, $n$-butanol, and diesel in a constant volume chamber," Energy \& Fuels, vol. 28, no. 10, pp. 6380-6391, 2014.

[23] H. Wu, K. Nithyanandan, J. Zhang et al., "Impacts of acetonebutanol-ethanol (ABE) ratio on spray and combustion characteristics of ABE-diesel blends," Applied Energy, vol. 149, pp. 367-378, 2015.

[24] H. Wu, T. H. Lee, C.-f. Lee, F. Liu, and B. Sun, "Optical soot measurement of bio-butanol upstream product, ABE (acetone-butanol-ethanol), under diesel-like conditions," Fuel, vol. 181, pp. 300-309, 2016.

[25] K. Nithyanandan, H. Wu, M. Huo, and C. F. Lee, "A preliminary investigation of the performance and emissions of a port-fuel injected SI engine fueled with acetone-butanolethanol (ABE) and gasoline," in Proceedings of the SAE 2014 World Congress \& Exhibition, Detroit, MI, USA, April 2014.

[26] Y. Li, K. Nithyanandan, T. H. Lee et al., "Effect of watercontaining acetone-butanol-ethanol gasoline blends on combustion, performance, and emissions characteristics of a spark-ignition engine," Energy Conversion and Management, vol. 117, pp. 21-30, 2016.

[27] Y. Li, L. Meng, K. Nithyanandan et al., "Experimental investigation of a spark ignition engine fueled with acetonebutanol-ethanol and gasoline blends," Energy, vol. 121, pp. 43-54, 2017.

[28] Z. Zhao, H. Wu, M. Wang et al., "Computational investigation of oxygen concentration effects on a soot mechanism with a phenomenological soot model of acetone-butanol-ethanol (ABE)," Energy \& Fuels, vol. 29, no. 3, pp. 1710-1721, 2015.

[29] J. Luo, Y. Zhang, Q. Zhang, J. Liu, and J. Wang, "Evaluation of sooting tendency of acetone-butanol-ethanol (ABE) fuels blended with diesel fuel," Fuel, vol. 209, pp. 394-401, 2017.

[30] X. Ma, F. Zhang, K. Han, and G. Song, "Numerical modeling of acetone-butanol-ethanol and diesel blends droplet evaporation process," Fuel, vol. 174, pp. 206-215, 2016.

[31] K. M. Van Geem, A. Cuoci, A. Frassoldati, S. P. Pyl, G. B. Marin, and E. Ranzi, "An experimental and kinetic modeling study of pyrolysis and combustion of acetone-butanol-ethanol (ABE) mixtures," Combustion Science and Technology, vol. 184, no. 7-8, pp. 942-955, 2012.

[32] S. Zhang, T. H. Lee, H. Wu, J. Pei, W. Wu, and F. Liu, "Experimental and kinetical study of component volumetric 
effects on laminar flame speed of acetone-butanol-ethanol (ABE)," Energy \& Fuels, vol. 32, no. 5, pp. 6278-6292, 2018.

[33] L. A. Graham, S. L. Belisle, and C.-L. Baas, "Emissions from light duty gasoline vehicles operating on low blend ethanol gasoline and E85," Atmospheric Environment, vol. 42, no. 19, pp. 4498-4516, 2008.

[34] P. S. Veloo, Y. L. Wang, F. N. Egolfopoulos, and C. K. Westbrook, "A comparative experimental and computational study of methanol, ethanol, and $n$-butanol flames," Combustion and Flame, vol. 157, no. 10, pp. 1989-2004, 2010.

[35] C. T. Chong and S. Hochgreb, "Measurements of laminar flame speeds of acetone/methane/air mixtures," Combustion and Flame, vol. 158, no. 3, pp. 490-500, 2011.

[36] T. Wallner, A. Ickes, and K. Lawyer, "Analytical assessment of C2-C8 alcohols as spark-ignition engine fuels," in Proceedings of the FISITA 2012 World Automotive Congress, pp. 15-26, Beijing, China, November 2012.

[37] Y. Li, L. Meng, K. Nithyanandan et al., "Combustion, performance and emissions characteristics of a spark-ignition engine fueled with isopropanol- $n$-butanol-ethanol and gasoline blends," Fuel, vol. 184, pp. 864-872, 2016.

[38] Y. Li, Y. Chen, G. Wu, C.-f. F. Lee, and J. Liu, "Experimental comparison of acetone- $n$-butanol-ethanol (ABE) and isopropanol- $n$-butanol-ethanol (IBE) as fuel candidate in sparkignition engine," Applied Thermal Engineering, vol. 133, pp. 179-187, 2018.

[39] G. Wu, Z. Lu, W. Pan, Y. Guan, S. Li, and C. Z. Ji, "Experimental demonstration of mitigating self-excited combustion oscillations using an electrical heater," Applied Energy, vol. 239, pp. 331-342, 2019.

[40] K. Key, T. Last, C. Haywood, and R. Raine, "Measurement of vapor pressures and enthalpies of vaporization of gasoline and ethanol blends and their effects on mixture preparation in an SI engine," SAE International Journal of Fuels \& Lubricants, vol. 1, no. 1, pp. 132-144, 2008.

[41] J. Zhang, K. Nithyanandan, Y. Li, C. F. Lee, and Z. Huang, "Comparative study of high-alcohol-content gasoline blends in an SI engine," in Proceedings of the SAE 2015 World Congress \& Exhibition, Detroit, MI, USA, April 2015.

[42] K. Nithyanandan, J. Zhang, Y. Li et al., "Improved SI engine efficiency using acetone-butanol-ethanol (ABE)," Fuel, vol. 174, pp. 333-343, 2016.

[43] G. Wu, Z. Lu, X. Xu et al., "Numerical investigation of aeroacoustics damping performance of a Helmholtz resonator: effects of geometry, grazing and bias flow," Aerospace Science and Technology, vol. 86, pp. 191-203, 2019.

[44] T. Topgül, H. S. Yücesu, C. Ç.ces, and A. Koca, "The effects of ethanol-unleaded gasoline blends and ignition timing on engine performance and exhaust emissions," Renewable Energy, vol. 31, no. 15, pp. 2534-2542, 2006.

[45] M. Canakci, A. N. Ozsezen, E. Alptekin, and M. Eyidogan, "Impact of alcohol-gasoline fuel blends on the exhaust emission of an SI engine," Renewable Energy, vol. 52, pp. 111-117, 2013.

[46] B. M. Masum, H. H. Masjuki, M. A. Kalam, I. M. Rizwanul Fattah, S. M. Palash, and M. J. Abedin, "Effect of ethanolgasoline blend on $\mathrm{NO}_{x}$ emission in SI engine," Renewable and Sustainable Energy Reviews, vol. 24, pp. 209-222, 2013.

[47] B. M. Gauthier, D. F. Davidson, and R. K. Hanson, "Shock tube determination of ignition delay times in full-blend and surrogate fuel mixtures," Combustion and Flame, vol. 139, no. 4, pp. 300-311, 2004.

[48] J. B. Heywood, Internal Combustion Engine Fundamentals, Mcgraw-Hill Education, New York, NY, USA, 1988.
[49] D. Dunn-Rankin, Lean Combustion: Technology and Control, Academic Press, Cambridge, MA, USA, 2011. 

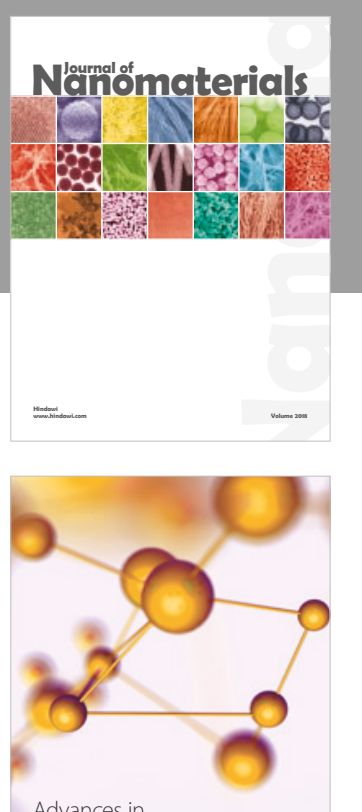

Physical Chemistry
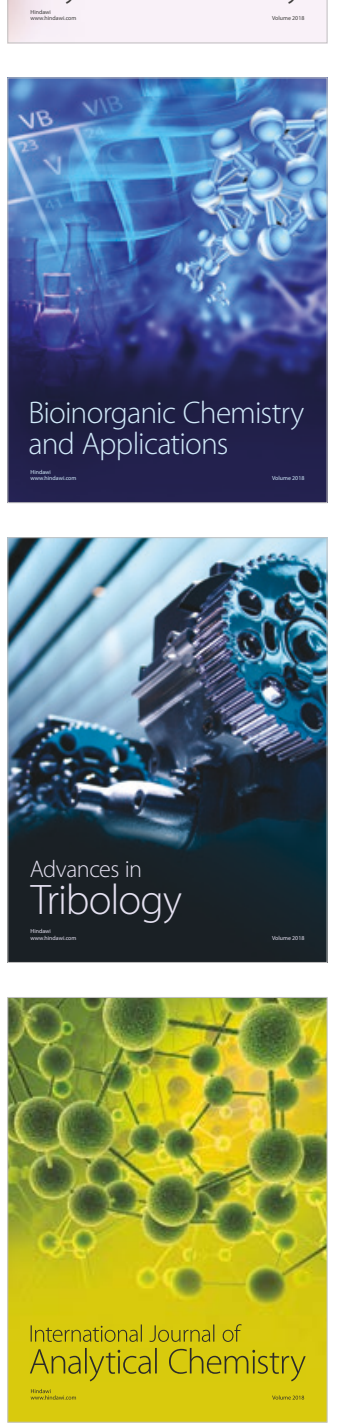

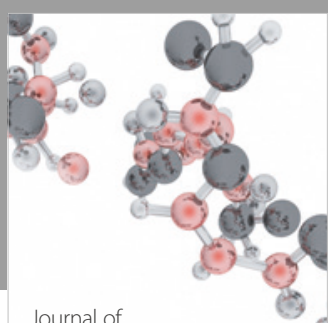

Analytical Methods

in Chemistry

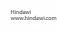

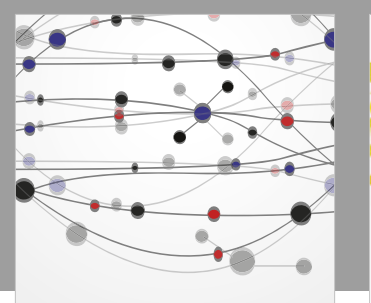

The Scientific World Journal

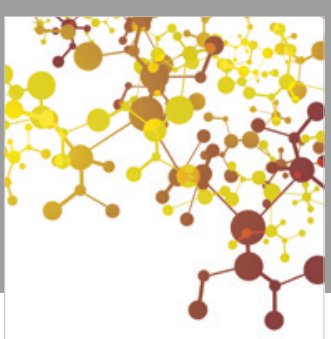

Journal of

Applied Chemistry
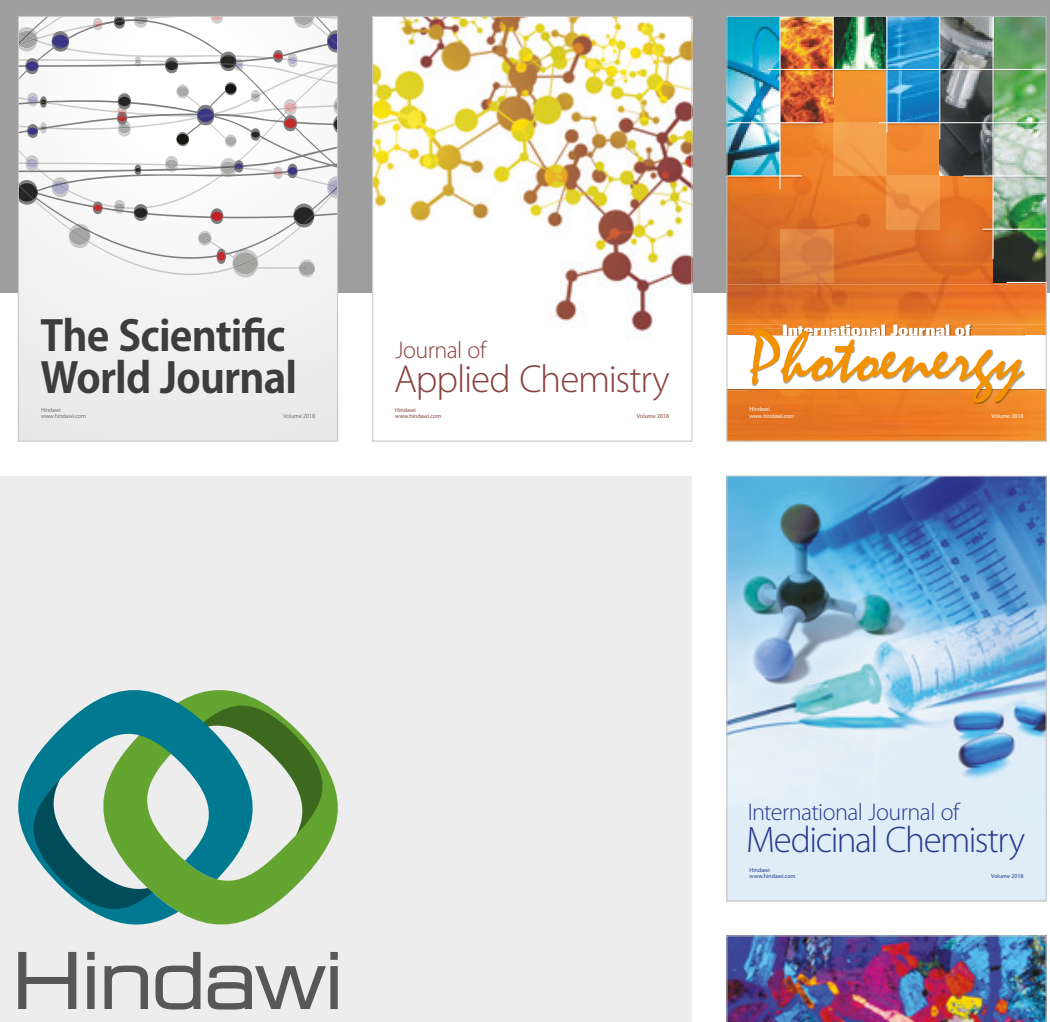

Submit your manuscripts at

www.hindawi.com
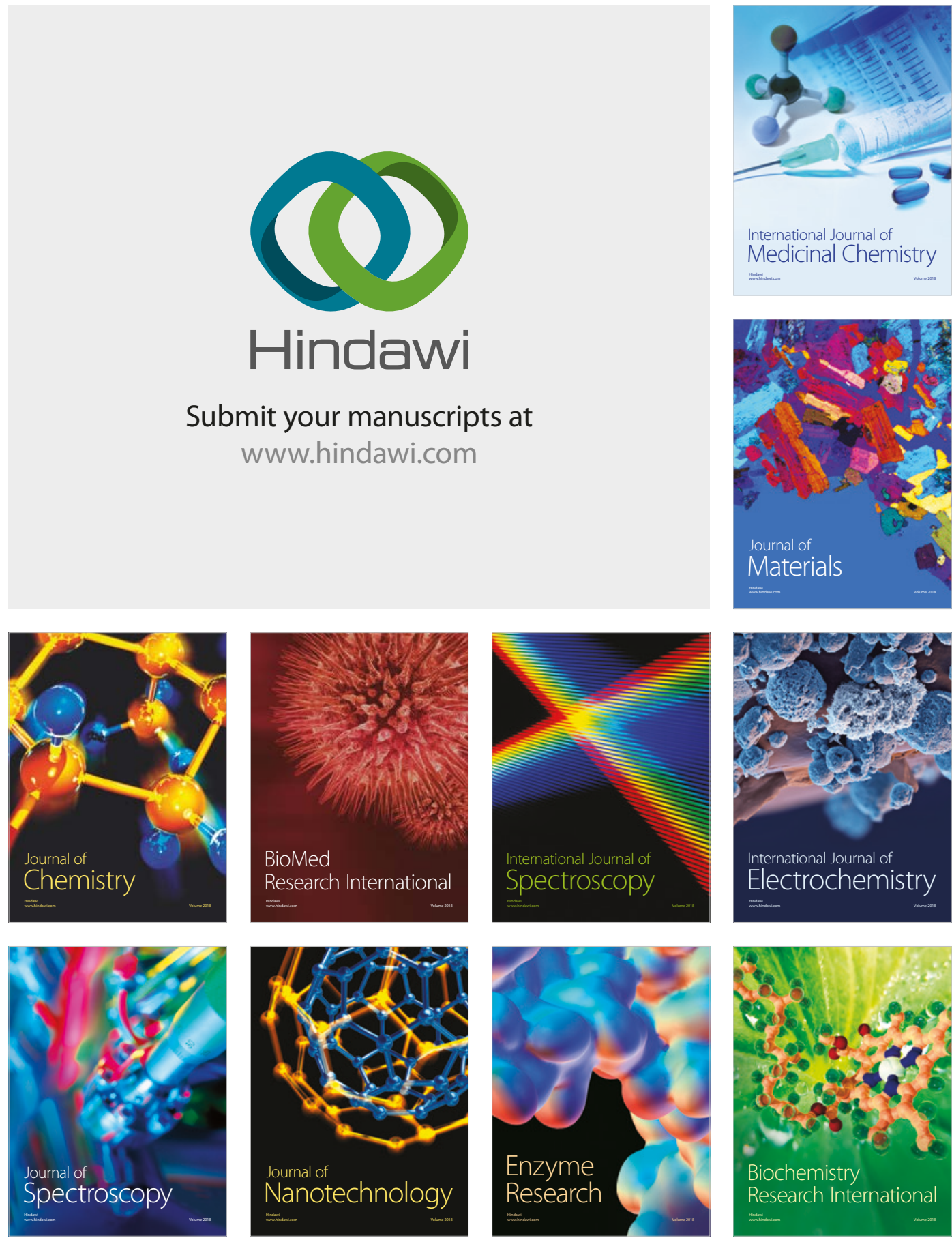
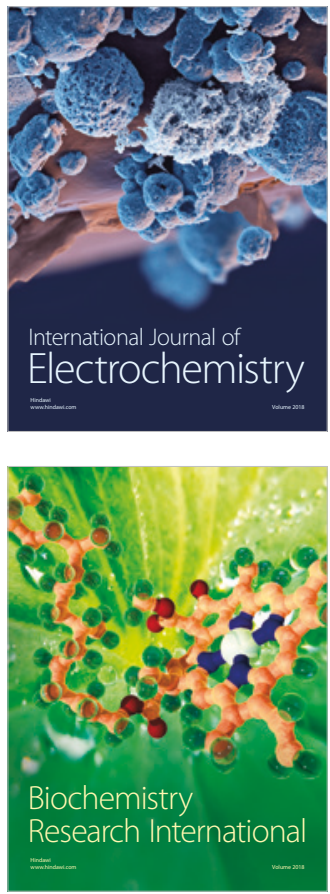